\title{
EFFECT OF ADDITION OF NATURAL PLANT EXTRACT ON THE FATTY ACID COMPOSITION AND STABILITY OF SOME VEGETABLE OILS DURING 12 MONTHES STORAGE PERIOD
}

\author{
ATTA, NAHED M.M. and AZZA A.A. AHMED
}

Oils and fat Res. Dept., Food Tech. Res. Ins., ARC, Giza, Egypt.

(Manuscript received 15 July 2012)

\begin{abstract}
Changes occurring in the physical and chemical properties refractive index (RI), Peroxide value (PV), free fatty acid (FFA), diene and triene at 232 and $268 \mathrm{~nm}$. stability and fatty acid composition of sunflower, soybean and their blend oils during storage for 12 months at room temperature in absence or presence rosemary and sage extracts (RE and SE) at ratio $200 \mathrm{ppm}$. and refined rice bran and sesame oil (RRBO and So) at ratio $3 \%$ as a rich source of natural antioxidant, were studied. The results flowed that. RI, PV, FFA and diene and triene at 232 and $268 \mathrm{~nm}$. of all previous these oils in absence and presence RE, SE, RRBO and So registered a progressive increase with increasing the storage period, but RE reduced the increase in these values compared to control oils flowed by RRBO and So then SE. On the other hand, stability of these oils were decreased by increasing storage time in absence and presence $R E, S E$, RRBO and So, while RE was more effective in preventing oils under study from oxidation when the oils were stored than other treated oils. During storage there is a gradual increase in $\mathrm{C}_{16: 0} 0$ and $\mathrm{C}_{18: 0}$ and a gradual decrease in $\mathrm{C}_{18: 1}$, $\mathrm{C}_{18: 2}$ and $\mathrm{C}_{18: 3}$ by increasing storage time of all oils under investigation, but additions of RE, SE, RRBO and So related to reduce the increase in saturated fatty acid and decrease in unsaturated fatty acid. Generally RE was superior to that of other addition increasing oils stability and quality.

Key words: Rosemary and sage extract, rice bran oil, sesame oil, physical and chemical properties, fatty acid composition and stability.
\end{abstract}

\section{INTRODUCTION}

The oils can be blended even to derive the protective advantage due to the presence of specific ingredient that offer protection against oxidation to improve frying recyclability (Toliwal et. al., 2005).

Oxidation of lipids not only produces vanced odours, unpleasant flavours and discoloration, but can also decrease the nutritional quality and safety. Use of antioxidants is one of the methods that retard or prevent lipid oxidation, preserve the quality and extend the shelf-life of food products. To avoid the use of synthetic additives, in recent decades, interest in natural antioxidants increased, especially because of the belief that natural food ingredients are safer than synthetics. Among 
the plants reported to have antioxidative activity, rosemary in its ground form or as an extract is widely used in many food applications. A number of components are responsible for the antioxidative properties of rosemary. The main antioxidative effect is attributed to three phenolic diterpenes: carnosic acid carnosal and rosmarinic acids (Helena and Veronika, 2006).

A power function was found to best represent the time dependence of the content of free radicals scavenged, as well as the content of $\beta$-carotene blaeched in the presence of rosemary extracts. (Petva et. al., 2009).

Rosemary is cultivated for the valuable oil which can be extracted from the harvested plants when flower is in buds. It is well known that the activity of rosemary extracts in food industry and medicine belongs to the presence of some important antioxidant oil and phenolic components, to prevent oxidative degradation of oil and lipid cantaining foods. (Eva et. al., 2003).

Extracts of many plants have been reported to have varying degrees of antioxidants activities in fats and oils. Results of these studies indicated clearly that the majority of the spices tested possessed some antioxidants activity, with rosemary (Rosmarinus officialis L.) and sage (Salvia officinalis L.) being the most potent. (Irwandi et. al., 2000).

The addition of natural plant extract of rosemary and sage leaves and refined rice bran oil to some vegetable oils caused remarkable increase in the induction period and total tocopherols and reduced the peroxide value, acidity and K232 and $268 \mathrm{~nm}$. of these oils. Also rosemary extract was superior to that of sage extract increasing oils stability and quality (Nahed 2010).

Several studies have been carried out on elucidating the physical and chemical properties of oil blends involving antioxidant properties of sesame oil which provides high levels of antioxidants and lignins, because of this, sesame oil is stable, and when mixed with other oils, actually increases the stability of the blend. (Gulla and Waghray 2011).

Rice bran is considered to be an important edible oil due to the presence of high percentage of unsaturated fatty acids and certain nutritionally and medicinally important minor constituents such as tocopherols, tocotrienols, sterols and oryzanol taking advantage of the valuable fact that micronutrient level are 50 adequate in rice bran oil. It was considered that value of any other edible oil could be remarkably increased by addition of even small amount of rice bran oil (Adhikari, 2002).

The aim of this work was to study the changes in the physical and chemical properties, fatty acid composition and stability of some oils as a results of addition rosemaiy and sage extracts and rice bran and sesame oils during storage. 


\section{MATERIALS AND METHODS}

\section{- Materials:}

1- Sunflower and saybean oils: Refined sunflower and soybean oils without antioxidant were obtained from El-Ekhowa Co. for processing oils. El Sadat city.

2- Blended oil: Refined sunflowers and soybean oil were mixed at 1: 1 ratio.

3- Refined rice bran oil (RRBO) and sesame oil (So) were obtained from CME group, ACME/Chicago Board of trade, NYmex company.

4- Plant leaves: The rosemary and sage leaves were collected from rosemary and sage plants of faculty of Agricultural farm (Cairo University).

\section{Methods:}

1- Preparation of natural plant extract (NPE) of Rosemary and Sage leaves (Methanolic extract).

The fresh rosemary and sage leaves were washed by tap water to remove any earth particles then air dried at $40^{\circ} \mathrm{C}$ over night and ground to obtain fine powder. The dried grounded leaves were extracted at room temp with methanol: water (80: $20 \%$ ) for 24 hours. Then extract was filtered through whatman paper (No.4). The filtrate of extracts were concentrated using rotary evaporator below $40^{\circ} \mathrm{C}$ under vacuum and air dried to remove the rest of solvent and ground to obtain a fine powder from NPE of rosemary and sage leaves.

2- Addition of NPE of rosemary, sage leaves, refined rice bran oil (RRBO) and sesame oil (3\% So) to oils (oils investigated).

- Sunflower oil without any addition (control).

- Sunflower oil + 3\% RRBO

- Sunflower oil + 3\% So.

- Sunflower oil + 200ppm from NPE of Rosemary leaves.

- Sunflower oil + 200 ppm from NPE of sage leaves.

- Soybean oils without addition (control)

- Soybean oils $+3 \%$ RRBO

- Soybean oils $+3 \%$ So

- Soybean oil + 200 ppm from NPE of Rosemary leaves.

- Soybean oil + 200 ppm from NPE of sage leaves.

- Blended oil (sun + soy 1: 1) without any addition (control)

- Blended oil $+3 \%$ RRBO

- Blended oil $+3 \%$ So

- Blended oil + 200ppm from NPE of Rosemary leaves

- Blended oil + 200 ppm from NPE of sage leaves 


\section{3- Storage of samples:}

Sunflowers, soybean and their blend oils in absence or presence rosemary extract (RE), sage extract (SE), Refined rice bran oil (RRBO) and sesame oil (So) were stored in dark glass bottles for 6 and 12 months at Room temp.

\section{4- Physical and chemical properties of oils.}

Refractive index: of oils was determined at $25^{\circ} \mathrm{C}$ according to A.O.A.C (2000) by using refractometer (NYRL -3 poland)

- Acid and peroxid values: were determined according to the methods of A.O.A.C. (1995).

- Absorbency in ultraviolet at 232 and $268 \mathrm{~nm}$. Ultraviolet and visible spectra were conducted using a pye unicum double beam recording spectrophotometer model sp1600, as described by Kates (1972). The samples were dissolved in freshly distil cyclohexan and the absorption were taken at 232 and $268 \mathrm{~nm}$.

\section{5- Fatty acid composition:}

The fatty acid methyl esters were prepared using trans-esterifiction with cold methanolic solution of potassium hydroxd the fatty acid methyl esters were identified by GC-capillary column according to the methods of IOOC (2001).

\section{6- The stability of oils:}

The oxidative stabilities of oils were estimated by using 679 Rancimat (Metrohn Herisou, co., swizerland) at $100^{\circ} \mathrm{C}$ with an air flow rate of $20 \mathrm{lit} / \mathrm{hr}$ according to the method described by Mendz et. al., (1997).

\section{RESULTS AND DISCUSSION}

Changes in refractive index at $25^{\circ} \mathrm{C}$ for oils (RI):

Data in Table (1) illustrated that the change in RI at $25^{\circ} \mathrm{C}$ of sunflower, soybean and their blend oils during storage for 12 months at room temperature in control samples and treated sample with RE (200ppm), SE (200ppm), RRBO (3\%) and So $(3 \%)$. From the results in this table, it could be observed that the refractive index increased gradually during storage in all oils studied. The changes in refractive index of oils may be attributed to propagation of auto oxidation reaction. Also the results indicated that, the refractive index of storage treated sunflower, soybean and their blended oils with $\mathrm{RE}, \mathrm{SE}$, RRBO and So were lower than control samples during storage. Samples related to the phenolic compound of rosemary and sage extract and antioxidant in ricebran and sesame oil exhibited the decrease in the oil refractive index phenomenon (Nahed, 2010). 
Table. 1. Changes in refractive index at $25^{\circ}$ of studied oils during storage.

\begin{tabular}{|l|l|l|l|}
\hline \multicolumn{1}{|c|}{ Oils } & Control & 6 month & 12 month \\
\hline Sunflower oil (control) & 1.4739 & 1.4745 & 1.4749 \\
Sunflower oil +RRBO & 1.4737 & 1.4740 & 1.4742 \\
Sunflower oil + RE & 1.4732 & 1.4736 & 1.4741 \\
Sunflower oil + SE & 1.4732 & 1.4737 & 1.4744 \\
Sunflower oil + So & 1.4738 & 1.4742 & 1.4740 \\
Soybean oil [control] & 1.4736 & 1.4741 & 1.4745 \\
Soybean oil + RRBO & 1.4732 & 1.4735 & 1.4739 \\
Soybean oil +RE & 1.4720 & 1.4723 & 1.4737 \\
Soybean oil + SE & 1.4730 & 1.4734 & 1.4736 \\
Soybean oil + So & 1.4734 & 1.4738 & 1.4741 \\
Blended oil [control] & 1.4736 & 1.4743 & 1.4746 \\
Blended oil + RRBO & 1.4735 & 1.4740 & 1.4744 \\
Blended oil + RE & 1.4732 & 1.4736 & 1.4740 \\
Blended oil + SE & 1.4731 & 1.4737 & 1.4741 \\
Blended oil + So & 1.4736 & 1.4740 & 1.4743 \\
\hline
\end{tabular}

RRBO $\rightarrow 3 \%$ Refined rice bran oil

$\mathrm{RE} \rightarrow 200 \mathrm{ppm}$ from NPE of rosemary leaves

SE $\rightarrow$ 200ppm from NPE of sage leaves

So $\rightarrow 3 \%$ sesame oil.

\section{Change in peroxide value}

Storage changes in sunflower, soybean and their blend oils were measured by the peroxide formation of the final products of oxidation. The changes in the peroxide values of selected oils during storage are seen in Table (2). Peroxide values of sample oils and control stored for 12 months registered a progressive increase with the storage periode. Steady increase in the oil sample under study according to the extent of oxidation caused by the formation of hydroperoxides during oil oxidation was observed. It was observed that the increase in peroxide values of control samples were from $0.24,0.63$ and $0.52 \mathrm{meg} / \mathrm{kg}$ to $9.35,8.04$ and $8.97 \mathrm{meg} / \mathrm{kg}$ after the 6 months of storage and to $25.4,18.63$ and $20.65 \mathrm{meg} / \mathrm{kg}$ after the 12 months of storage in sunflower, soybean and, their blend oils respectively. But the presence of rosemary and sage extract at $200 \mathrm{ppm}$ and also the refined rice bran and sesame oils at $3 \%$ in the previous oils reduced the peroxide values during storage for 6 and 12 months by more than $50 \%$ as compared to control oils. This may be due to the presence of natural antioxidants such as polyphenols and flavanoids components in 
rosemary and sage extracts (Nahed 2010) and tocopherols, tocotrienols, sterals and oryzanol in rice bran oil (Adhikari, 2002) also sesame oil cantain high levels of antioxidants and lignins (Sankar et. al., 2003).

\section{Change in free fatty acid :}

The changes in free fatty acid values, expressed as oleic acid percent of control samples ( sunflower, soybean, and their blend ) and treated sample with , rosemary and sage extract (200 ppm), refined rice bran oil (3\%) and sesame oil (3\%) during storage for 12 monthe is depicted in Table (3). The FFA of control were seem to be $0.5,0.62$ and $0.58 \%$, which increased slowly and steadily to 1.12 ,

Table. 2. Changes in peroxide value of studied oils during storage.

\begin{tabular}{|c|c|c|c|}
\hline Oils & Control & 6 month & 12 month \\
\hline Sunflower oil (control) & 0.24 & 9.25 & 25.42 \\
\hline Sunflower oil +RRBO & 0.14 & 6.93 & 14.62 \\
\hline Sunflower oil + RE & 0.13 & 4.23 & 10.93 \\
\hline Sunflower oil + SE & 0.19 & 8.25 & 17.30 \\
\hline Sunflower oil + So & 0.20 & 5.42 & 13.75 \\
\hline Soybean oil [control] & 0.63 & 8.04 & 18.63 \\
\hline Soybean oil + RRBO & 0.40 & 7.03 & 15.73 \\
\hline Soybean oil +RE & 0.16 & 3.75 & 9.51 \\
\hline Soybean oil + SE & 0.39 & 7.74 & 16.03 \\
\hline Soybean oil + So & 0.37 & 5.62 & 11.54 \\
\hline Blended oil [control] & 0.52 & 8.97 & 20.69 \\
\hline Blended oil + RRBO & 0.29 & 6.3 & 13.40 \\
\hline Blended oil + RE & 0.38 & 4.0 & 9.71 \\
\hline Blended oil + SE & 0.45 & 7.82 & 15.26 \\
\hline Blended oil + So & 0.41 & 5.8 & 11.95 \\
\hline
\end{tabular}

1.2 and $1.17 \%$ after storage period of 6 months and to $2.60,2.7$ and $2.34 \%$ after storage period of 12 months in sunflower, soybean and their blend oils respectively. The hydrolytic changes though not predominant, the formation of FFA was found to increase with the increase in time of storage, but the free fatty acids of these oils bended with rosemary and sage extract (200ppm) and with rice bran and sesame oils (3\%) were lower after storage period of 6 and 12 months compared with control samples. This may be due to the high content of natural antioxidants in rosemary and sage extract and rice bran and sesame oils. On the other hand RE (rosemary extract) 
was more effective in preventing oil from hydrolysis and oxidation when the oils samples were stored.

Table. 3. Changes in free fatty acids (FFA) of studied oils during storage.

\begin{tabular}{|l|l|l|l|}
\hline Oils & Control & 6 month & 12 month \\
\hline Sunflower oil (control) & 0.50 & 1.12 & 2.6 \\
Sunflower oil +RRBO & 0.46 & 0.9 & 1.20 \\
Sunflower oil + RE & 0.34 & 0.72 & 1.01 \\
Sunflower oil + SE & 0.46 & 1.01 & 1.9 \\
Sunflower oil + So & 0.36 & 0.8 & 1.12 \\
Soybean oil [control] & 0.62 & 1.2 & 2.7 \\
Soybean oil + RRBO & 0.56 & 0.97 & 1.29 \\
Soybean oil +RE & 0.33 & 0.74 & 1.12 \\
Soybean oil + SE & 0.36 & 1.20 & 1.94 \\
Soybean oil + So & 0.54 & 0.82 & 1.18 \\
Blended oil [control] & 0.58 & 1.17 & 2.34 \\
Blended oil + RRBO & 0.20 & 0.95 & 1.24 \\
Blended oil + RE & 0.30 & 0.73 & 1.07 \\
Blended oil + RE & 0.32 & 1.14 & 1.92 \\
Blended oil + So & 0.23 & 0.82 & 1.15 \\
\hline
\end{tabular}

\section{Changes in diene and triene:}

The changes in diene and triene value at 232 and $268 \mathrm{~nm}$. of sunflower soybean and their blend oils during storage in absence (control samples) and presence RE, SE, RRBO and So for 12 months at room temperature can be seen in Table (4). Higher increase in diene and triene values could be noticed between the initial and final period of storage control oils, but the increase in these values was reduced in treated samples with plant extracts (RE and SE) and RRBO and so, especially in presence of rosemary extract. The higher increase of diene and triene values at 232 and $268 \mathrm{~nm}$. in control samples indicated the deterioration and oxidation of oils during storage, but the addition of $\mathrm{RE}, \mathrm{SE}, \mathrm{RRBO}$ and So caused reduce in these values this may be due to, those products containing important minor and antioxidant components such as polyphenols and falvonoids in rosemary and sage extracts (Nahed 2010) and tocopherols, tocotrienols, sterols and oryzanol in rice bran oil (Gualla and Waghray, 2011) and lignins in sesame oil (Sankar et. al. 2003). These components when mixed with oils actually delay oil oxidation and increases the stability of oils (Nahed 2010). 


\section{Changes in stability of oils:}

The presented data in Table (5) showed the changes of stability of sunflower, soybean and their blend oil in absence (control) and presence of RE, SE, RRBO and So during storage at for 12 months at room temperature. The stability of control oils recorded a higher decreased by increasing storage period, also there was a steady decrease in stability of these oils in presence of $\mathrm{RE}, \mathrm{SE}, \mathrm{RRBO}$ and So during storage, but this decrease was seem to be the least in comparison to control samples. The nutritional contribution of the three minor components of tocopherol,

Table. 4. Changes in diene and triene of studied oils during storage.

\begin{tabular}{|l|c|c|c|c|c|c|}
\hline \multirow{2}{*}{\multicolumn{1}{|c|}{ Oils }} & \multicolumn{2}{|c|}{ Control } & \multicolumn{2}{c|}{6 month } & \multicolumn{2}{c|}{12 month } \\
\cline { 2 - 8 } & $232 \mathrm{~nm}$ & $268 \mathrm{~m}$ & $232 \mathrm{~nm}$ & $268 \mathrm{~m}$ & $232 \mathrm{~nm}$ & $268 \mathrm{~m}$ \\
\hline Sunflower oil [control] & 2.627 & 1.593 & 2.795 & 1.612 & 2.964 & 1.631 \\
Sunflower oil +RRBO & 2.646 & 1.396 & 2.798 & 1.421 & 2.850 & 1.472 \\
Sunflower oil + RE & 2.517 & 1.481 & 2.683 & 1.485 & 2.750 & 1.590 \\
Sunflower oil + SE & 2.610 & 1.662 & 2.745 & 1.675 & 2.880 & 1.644 \\
Sunflower oil + So & 2.576 & 1.579 & 2.688 & 1.581 & 2.800 & 1.598 \\
Soybean oil [control] & 2.614 & 1.40 & 2.770 & 1.518 & 3.930 & 1.630 \\
Soybean oil + RRBO & 2.636 & 1.479 & 2.660 & 1.487 & 2.920 & 1.526 \\
Soybean oil +RE & 2.649 & 0.931 & 2.680 & 1.231 & 2.780 & 1.056 \\
Soybean oil + SE & 2.648 & 1.143 & 2.690 & 1.321 & 3.02 & 1.570 \\
Soybean oil + So & 2.583 & 1.459 & 2.650 & 1.485 & 2.940 & 1.550 \\
Blended oil [control] & 2.600 & 1.403 & 2.780 & 1.545 & 2.995 & 1.584 \\
Blended oil + RRBO & 2.657 & 1.684 & 2.6800 & 1.740 & 2.903 & 1.761 \\
Blended oil + RE & 2.399 & 1.230 & 2.560 & 1.432 & 2.654 & 1.352 \\
Blended oil + SE & 2.645 & 1.345 & 2.693 & 1.532 & 2.996 & 1.422 \\
Blended oil + So & 2.615 & 1.579 & 2.785 & 1.664 & 2.850 & 1.650 \\
\hline
\end{tabular}

tocotrienols and $\delta$-oryzanol in rice bran oil may have confermed this greater oxidative stability (Gutla and Waghrayo 2011), also sesame oil is stable, and when mixed with other oils, actually increases the stability of the blend (Nirmala et. al., 1996 and Sankar et. al., 2003), and also rosemary and sage are two plant sources of antioxidants that have been studied intensively and proven effective for stabilizing frying oils (Irwandi et. al., 2000). 
Table. 5. Changes in oxidative stability of studied oils during storage.

\begin{tabular}{|l|c|c|c|}
\hline \multicolumn{1}{|c|}{ Oils } & Control & 6 month & 12 month \\
\hline Sunflower oil (control) & 10.90 & 6.76 & 1.20 \\
Sunflower oil +RRBO & 12.02 & 7.16 & 6.10 \\
Sunflower oil + RE & 14.61 & 8.31 & 6.90 \\
Sunflower oil + SE & 13.50 & 5.21 & 5.20 \\
Sunflower oil + So & 11.53 & 8.13 & 7.09 \\
Soybean oil [control] & 14.52 & 8.92 & 5.50 \\
Soybean oil + RRBO & 15.41 & 8.87 & 6.00 \\
Soybean oil +RE & 16.1 & 10.20 & 7.60 \\
Soybean oil + SE & 15.40 & 8.41 & 5.10 \\
Soybean oil + So & 15.52 & 9.26 & 6.80 \\
Blended oil [control] & 11.91 & 7.50 & 4.20 \\
Blended oil + RRBO & 14.20 & 8.43 & 6.30 \\
Blended oil + RE & 15.00 & 9.33 & 8.60 \\
Blended oil + SE & 12.90 & 7.73 & 6.07 \\
Blended oil + So & 12.40 & 8.92 & 7.13 \\
\hline
\end{tabular}

\section{Changes in fatty acid composition of oil during storage:}

Changes in fatty acid composition during storage for 6 and 12 months at room temperature for sunflower, soybean and their blend oils in absence or presence rosemary extract (RE), sago extract (SE) refined rice brane oil (RRBO) and sesame oil (So) are shown in Tables (6, 7 and 8). The results indicated that, during storage there was a gradual increase in $C_{16: 0}$ and $C_{18: 0}$ but a decrease in $C_{18: 1}, C_{18: 2}$ and $C_{18: 3}$ of all previous oils in absence (control samples) or presence RE, SE, RRBO and SO (treated samples). This may probably be due to oxidative cleavage of these fatty acids on storage (Gulla and Waghray 2011), with regard the results in all tables, the gradual increase in saturated fatty acids $\left(\mathrm{C}_{16: 0}\right.$ and $\left.\mathrm{C}_{18: 0}\right)$ and a decrease in unsaturated fatty acids $\left(\mathrm{C}_{18: 1}, \mathrm{C}_{18: 2}\right.$ and $\left.\mathrm{C}_{18: 3}\right)$ of sunflower, soybean and their blend oils were reduced in presence RE flowed by So and RRBO then SE compared to control samples. This may be due to RE, SE, RRBO and So are rich source with antioxidants which prevent lipid oxidation.

In conclusion rosemary extracts more effective in preventing oils from oxidation than the other addition under study during storage. 
Table. 6 . Changes in the fatty acid compisiton of sunflower oils during storage.

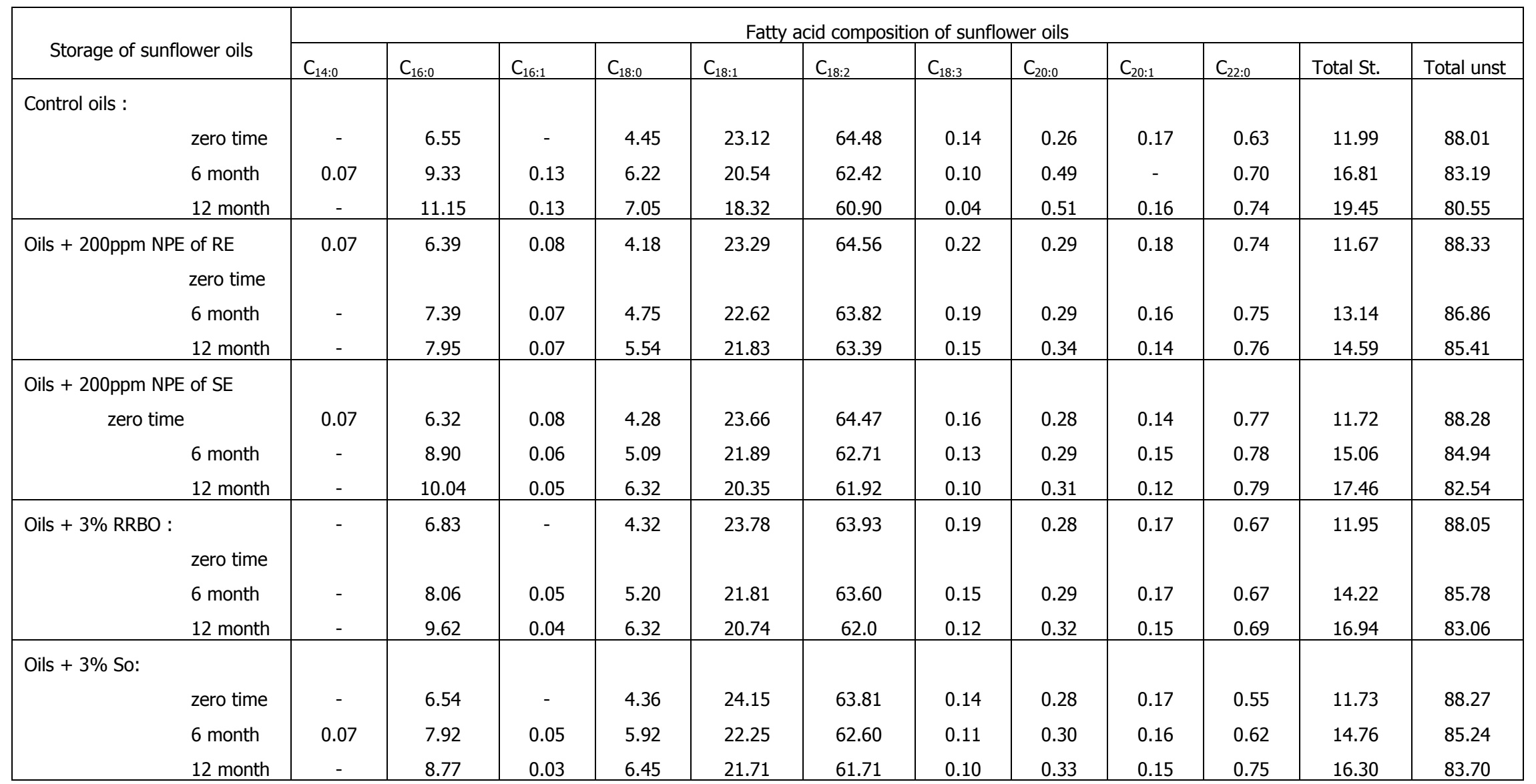


Table. 7. Changes in fatty acid composition of soybean oils during storage.

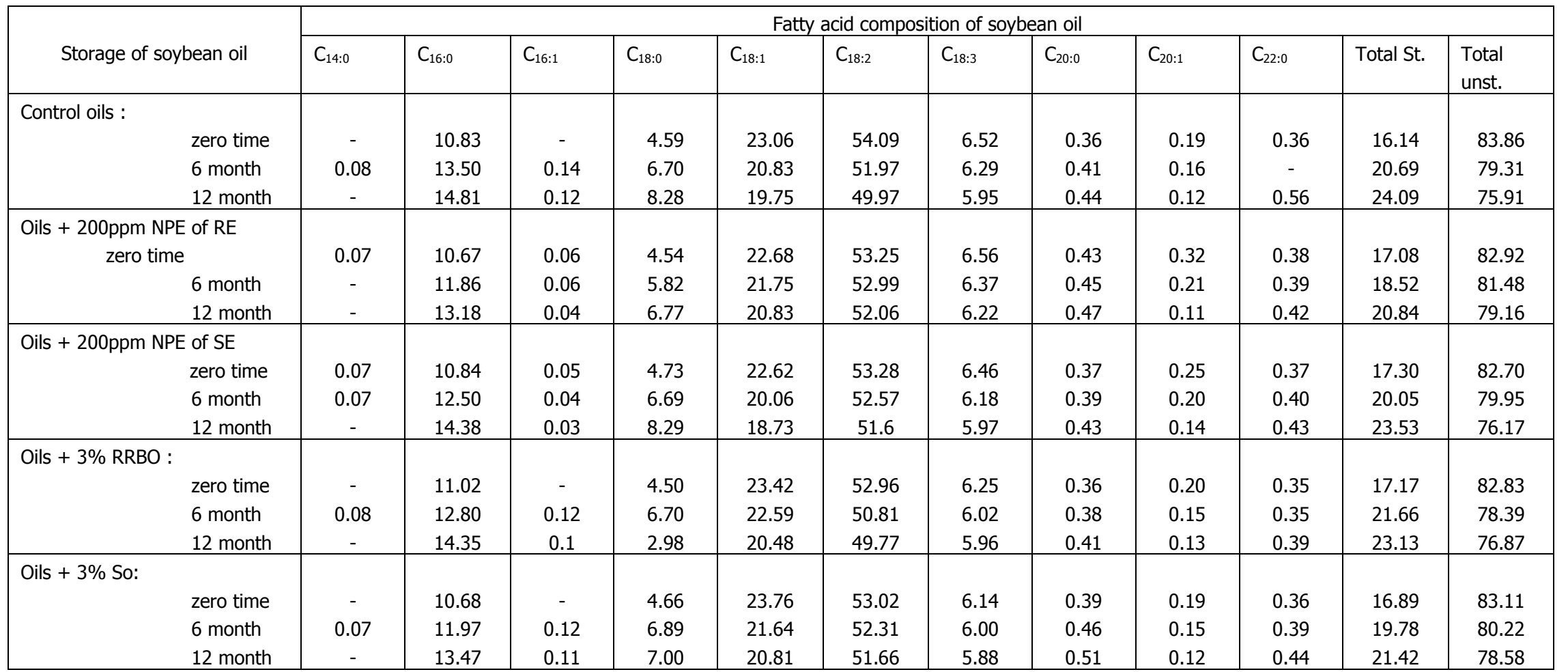


Table. 8. Changes in fatty acid composition of blended oils during storage.

\begin{tabular}{|c|c|c|c|c|c|c|c|c|c|c|c|c|c|}
\hline \multirow{2}{*}{\multicolumn{2}{|c|}{ Storage of blended oils }} & \multicolumn{12}{|c|}{ Fatty acid composition of blended oils } \\
\hline & & $C_{14: 0}$ & $\mathrm{C}_{16: 0}$ & $\mathrm{C}_{16: 1}$ & $C_{18: 0}$ & $\mathrm{C}_{18: 1}$ & $C_{18: 2}$ & $\mathrm{C}_{18: 3}$ & $\mathrm{C}_{20: 0}$ & $\mathrm{C}_{20: 1}$ & $\mathrm{C}_{22: 0}$ & Total St. & $\begin{array}{l}\text { Total } \\
\text { unst. }\end{array}$ \\
\hline \multirow[t]{4}{*}{ Control oils : } & & & & & & & & & & & & & \\
\hline & zero time & - & 8.19 & - & 4.39 & 23.17 & 59.52 & 3.32 & 0.31 & 0.17 & 0.52 & 13.99 & 87.01 \\
\hline & 6 month & 0.09 & 11.94 & 0.18 & 6.17 & 20.94 & 56.57 & 3.04 & 0.40 & 0.13 & 0.54 & 19.14 & 80.66 \\
\hline & 12 month & - & 13.61 & 0.08 & 7.81 & 19.38 & 55.13 & 2.89 & 0.42 & 0.10 & 0.58 & 22.38 & 77.62 \\
\hline \multicolumn{14}{|c|}{ Oils + 200ppm NPE of RE } \\
\hline & zero time & 0.07 & 8.97 & 0.15 & 4.34 & 23.88 & 59.35 & 3.26 & 0.08 & 0.20 & 0.67 & 13.20 & 86.79 \\
\hline & 6 month & 0.07 & 9.11 & 0.10 & 5.62 & 22.83 & 58.97 & 3.16 & 0.34 & 0.12 & 0.68 & 15.82 & 84.18 \\
\hline & 12 month & - & 9.63 & 0.06 & 6.12 & 22.18 & 57.83 & 3.00 & 0.47 & - & 0.71 & 16.93 & 83.07 \\
\hline \multicolumn{14}{|c|}{ Oils + 200ppm NPE of SE } \\
\hline & zero time & 0.07 & 8.97 & 0.11 & 4.34 & 22.94 & 58.99 & 3.34 & 0.31 & 0.20 & 0.56 & 14.41 & 85.59 \\
\hline & 6 month & 0.09 & 10.85 & 0.07 & 6.82 & 21.31 & 56.78 & 3.16 & 0.33 & - & 0.59 & 18.68 & 81.32 \\
\hline & 12 month & - & 12.42 & 0.06 & 7.29 & 20.51 & 55.66 & 3.07 & 0.37 & - & 0.62 & 20.70 & 79.30 \\
\hline \multicolumn{14}{|c|}{ Oils + 3\% RRBO : } \\
\hline & zero time & - & 8.97 & - & 4.34 & 23.78 & 58.10 & 3.26 & 0.33 & 0.19 & 0.52 & 14.67 & 85.33 \\
\hline & 6 month & 0.08 & 10.22 & 0.13 & 6.09 & 22.81 & 56.89 & 3.12 & 0.35 & 0.14 & 0.56 & 17.31 & 82.70 \\
\hline \multicolumn{14}{|l|}{ Oils + 3\% So: } \\
\hline & zero time & - & 8.62 & - & 4.44 & 23.98 & 58.31 & 3.18 & 0.33 & 0.18 & 0.49 & 14.35 & 85.65 \\
\hline & 6 month & - & 9.45 & 0.14 & 5.85 & 23.73 & 56.69 & 3.10 & 0.38 & 0.15 & 0.51 & 16.19 & 83.81 \\
\hline & 12 month & - & 10.35 & 0.12 & 6.92 & 22.48 & 56.06 & 3.02 & 0.42 & 0.10 & 0.53 & 18.22 & 81.78 \\
\hline
\end{tabular}




\section{REFERENCES}

1. A.O.A.C. 1995. Official methods of analysis the Association of Official Analytical Chemists published by the A.O.A.C $16^{\text {th }}$ Ed. Washington, D.C.

2. A.O.A.C. 2000. Official methods of analysis the associationof official analytical chemists, published by the A.O.A.C $17^{\text {th }}$ Ed., Washington, D.C.

3. Adhkari, J. 2002. Enriching of oil RBO's Midas touch SAARC oils and fats today, August, 15-17.

4. Eva, S., M.H. Tulok, A. Hegedus, C. Remmor, I.S. Varga. 2003. Antioxidant effect of various rosemary (Rosmarinus officinalis L.) clones. Acta Biologica szegediensis, 47 (1-4): 111-113.

5. Gulla, S., K. Waghray. 2011. Effect of storage on physico-chemical characteristics and fatty acid composition of selected oil blends. JLS, 3 (1): 35-46.

6. Helena, A., A. Veronika. 2006. Effect of added rosemary extract on oxidative stability of camelina sativa oil. Acta Agriculture slovenica, 87 (2): 255-261.

7. IOOC. 2001. Method of analysis of the international olive oil council preparation of the fatty acid methyl ester from olive oil and olive pomace oil. COI/T. 2.0/ Doc No.24.

8. Irwandi, J., Y.B. Cheman, D.D Kitts. 2000. Synergistic effects of rosemary, sage and citric acid on fatty acid retention of palm olein during deep-fat frying. AOCS, 77 (5): 527-534.

9. Kates, N. 1972. Techniques of lipidology American Elsevist publishing Co. Inc. New York.

10. Medez, E., J. Sanhveza, H. Spisky, A. Valenzuion. 1997. Comparison of rancimat evaluation method to assess oxidative stability of fish oil. JAOCS, 74 (3) 330-333.

11. Nahed, M.M. Atta. 2010. Extension of induction period of some vegetable oils by using natural plant extract (NPE) and refind rice bran oil. Egypt, J. Agric Res., 88 (3): 831-842.

12. Nirmala, KM., A., Chitran , R., Parvatham. 1996. Quality and storage stability of crude palm oil and its blends. The Ind J Nutr Dietet, 33: 238-249.

13. Petra, T, B., Miran, A. Helena. 2009. A kinetic model for evaluation of the antioxidant activity of several rosemary extracts. Food chem. 115, 740-744.

14. Sankar, D, KV Pugakndi, G.S Samban dam, MR. Rao. 2003. sesano oil helps reduce dose of blood pressure-cowering medicine. Meeting report. 4/28/2000, from<http://www.american heart.org/ presenter (Retrieved on 12th December, 2003).

15. Toliwal SD, MR Tiwari, S. Vermo. 2005. Studies on thermal stability of palm -corn oil blends. J oil Technol Assoc India, 37 (3): 18-20. 


\section{تأثير إضافة مستخلص نبات طبيعى على تركيب الأحماض الدهنية والثبات لبعض}

\section{الزيوت النباتية أثناء التخزين لفترة 12 شهرا}

ناهد محمد محروس عطا , عزة عبد الله أحمد أحمد

$$
\text { قسم بحوث الزيوت والدهون - معهد تكنولوجيا الأغذية - مركز البحوث الزراعية - جبزة }
$$

تم دراسـة التغيرات التى تحدث فـى الخـواص الطبيعيـة والكيميائيـة [معامـل الانكسـار - رقم البيروكسيد - رقم الحموضـة - القياس فى منطقة الـ ل على طول موجى 232، 268 نانوميتز والثبات] وتركيب الأحماض الدهنية أثناء التخزين لزيوت عباد الثمس والصويا وخليطهم لمدة 6، 12 شهر على درجة حرارة الغرفة فى غياب أووجود مستخلص حصى ألبان والمرمرية بنسبة 200 جزء فى ولى المليون وأيضاً إضافة زيت رجيع الكون المكرر والسمسم بنسبة 3\% كمصدر غنى بمضادات الأكسدة الطبيعية. وقد تبين من النتائج الآتى. معامل الانكسار ، رقم البيروكسيد والحموضة والقياس فى منطقة الـ

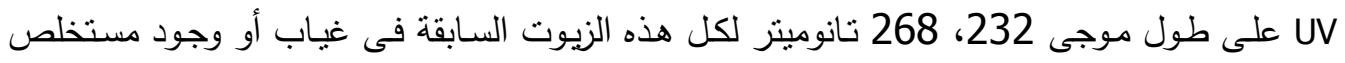
حصى ألبان والمرمرية وزيوت رجيع الكون المكرر والسمسم سجلت زيادة تدريجية بزيادة فترة التخزين ولكن مستخلص حص البان سبب نقص الزيادة فى هذه الأرقام مقارنة بالكنترول يليه زيت رجيع الكون

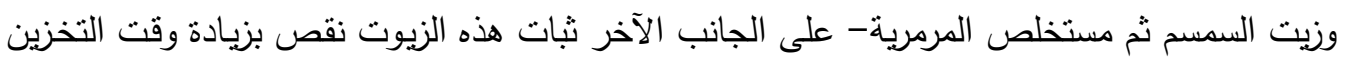

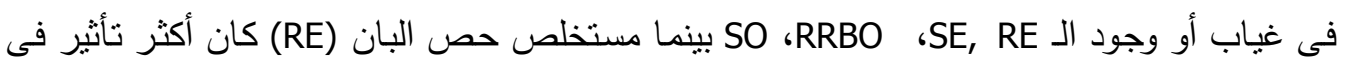
حماية الزيوت المخزنة موضع الدراسة من الأكسدة عن باقى الزيوت المعاملة مقارنة بزيوت الكنترول.

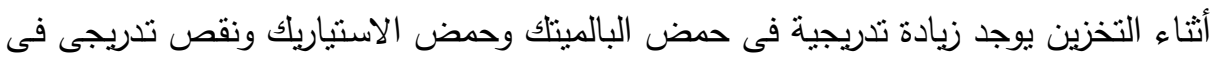

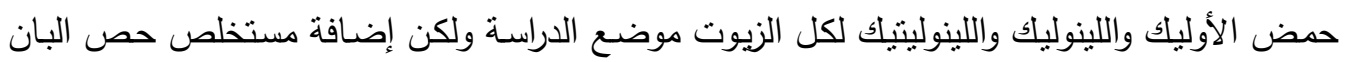

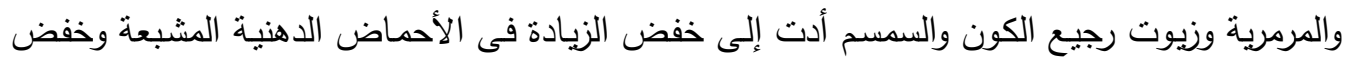
النقص فى الأحماض الدهنية الغير مشبعة. وعموماً تفوق مستخلص حصى البان على باقى الإضـافات الأخرى وذلك من خـلال زيادة

$$
\text { ثبات الزيوت وخواص الجودة. }
$$

